\title{
THE INFLUENCE OF RELIEF ON MICROCLIMATE AND LOCATION OF THE UPPER TREE-LIMIT
}

\author{
STANISŁAW KĘDZIA \\ Institute of Geography and Spatial Organization, Polish Academy of Science, \\ św. Jana 22, 31-018 Kraków, Poland, \\ E-mail: kedzia@zg.pan.krakow.pl
}

\begin{abstract}
In the hitherto works concerning the course of the upper tree-limit or mountain pine-limit and their relation with mean annual temperature, the limits of vegetation horizons were determined much more precisely than the location of isotherms - the latter were determined basing on interpolation and extrapolation of data from meteorological stations. Thanks to the application of Onset HOBO data loggers, the measurements of air temperature were carried out in selected sites at the upper tree-limit in Sucha Woda Valley in the Tatra Mountains. The measurements were conducted every hour during 4 months in warm period in 2007. The measurement sites were located in different land reliefs of different exposition. The lowest temperature was recorded in the depression of a channel shape located about $100 \mathrm{~m}$ below the other sites. Also in the next site located in a concave land form - the bottom of the Czarny Potok valley, the recorded temperature was lower than in the sites located in non-dismembered area. Despite the fact that the investigations had only a preliminary character, they showed that the upper tree-limit and probably also the mountain pine-limit should not be compared with the course of mean annual temperatures determined basing on interpolation and extrapolation. Only direct measurements of temperature in the field give a true picture of relation between the relief and mictoclimate and the upper tree-limit.
\end{abstract}

KEY WORDS: relief, climate, tree-limit, the Tatra Mts.

\section{INTRODUCTION}

The problems connected with the location of the upper tree-limit or mountain pine-limit in the Polish part of the Tatras were widely discussed in many publication (Sokolowski 1928; Fabijanowski 1955, 1972; Myczkowski 1964; Hess 1965, 1974; Szafer 1966; Zientarski 1985; Kotarba 1987; Balon 1991a, b, 2000; Heikkinen et al. 1995; Krzemień et al. 1995; Piękoś-Mirkowa and Mirek 1996; Jodtowski 2007). The authors of those publications discussed the influence of different factors including climate (and its individual elements), relief or human impact on the course of the upper tree-limit and mountain pine-limit. One of the most often cited work is a fundamental work by Hess (1965) concerning vertical climatic zones in the Polish Western Carpathians. However, some of the authors express the opinion that the location of vegetation zones (including the tree-limit and mountain pine-limit) in fact departs, due to the climate itself, from vegetation zones determined by Hess. Unfortunately, a closer look to the research workshop of these authors reveals a large disproportion in determination of the course of limits of individual zones and the course of the limit isotherms. Inasmuch the limits of vegetation zones are determined in many works very precisely using topographic maps (including ortophoto- 
maps), GPS or altimeters, the course of isotherms is determined by extrapolation and interpolation of temperatures from meteorological stations. Such rigid ascription of temperatures to certain altitudes without including the influence of the relief on macro- or microclimate is usually burden with an error. Sometimes a large error. In order to determine the size of this error, the author decided to carry out preliminary investigations on the influence of relief on air temperature.

\section{STUDY AREA}

Because of the fact that a research station of the Institute of Geography and Spatial Organisation of Polish Academy of Sciences is located at Hala Gąsienicowa, where meteorological measurements are recorded, the Su- cha Woda Valley was chosen as a study area. At first, the zone of both the upper tree-limit and mountain pine-limit was included in the investigations. It was assumed that measurement sites were located in places where no essential influence of relief on the course of the limits was detected (avalanches, debris flows, large inclination of slopes, etc). Because of the fact that in the area of Hala Gąsienicowa it was difficult to find a site where the limit of mountain pine would be only influenced by climate, this site was excluded from the investigations. Four sites (Fig. 1, Tab. 1) within the zone of tree-limit were selected for measurement of air temperature.

In the area of Sucha Woda Valley, two measurement sites were located in Dubrawiska and Wolarczyska, because there is a natural and undisturbed (or almost not

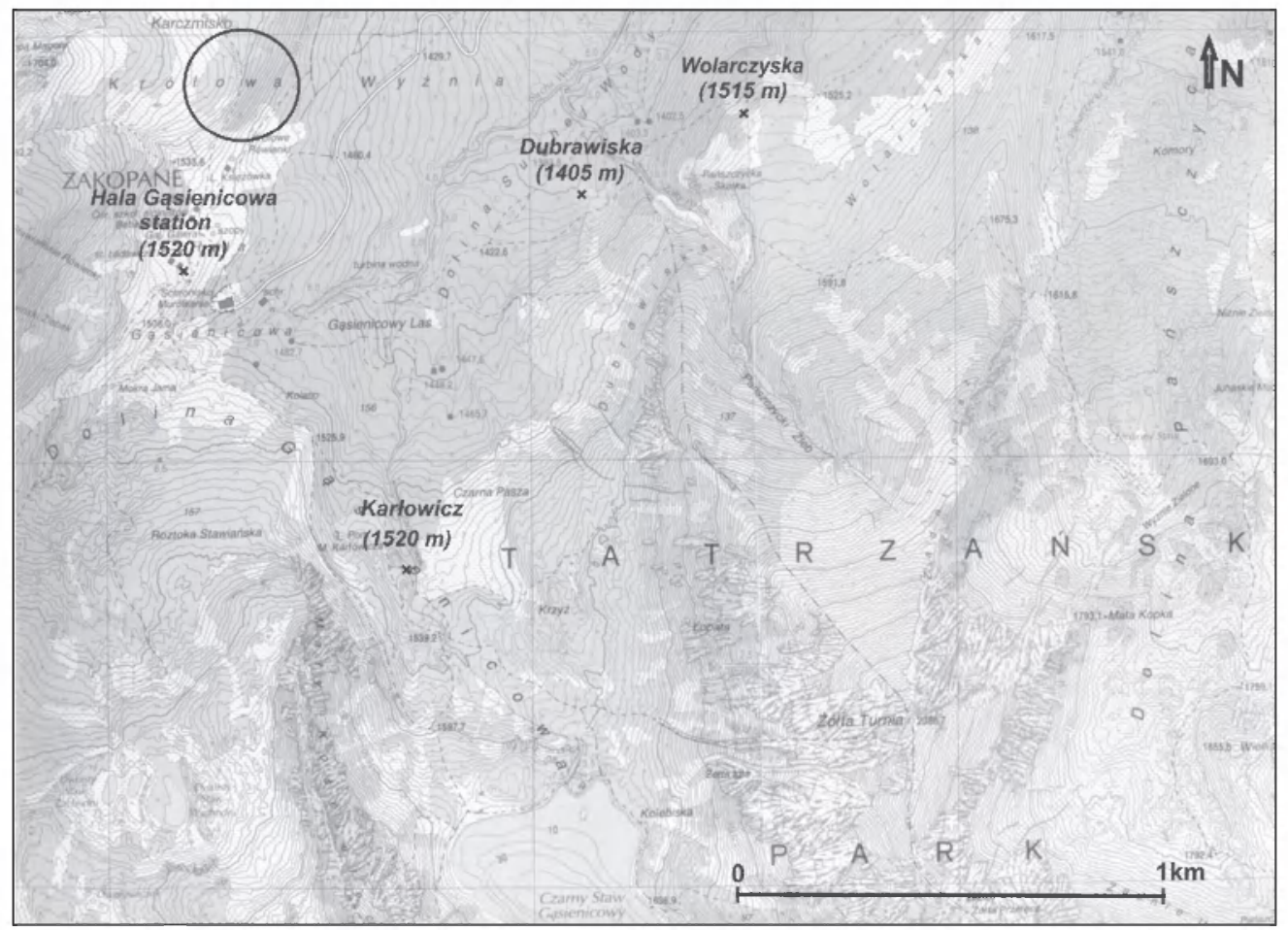

Figure 1. The map of investigation area with measurement sites. A circle shows the highest location of the upper tree-limit in Hala Gąsienicowa, the Tatra Mts.

Source: after the main Geodesist of the Country, 1997; permission of the Marshal of Malopolskie Voivodeship No. $12 / 2010$. 
Table 1. Description of measurement sites

\begin{tabular}{lll}
\hline Site & Altitude in m a.s.l. & Description \\
\hline $\begin{array}{l}\text { Hala Gąsienicowa } \\
\text { station }\end{array}$ & 1520 & $\begin{array}{l}\text { Meteorological station, slope of the SE exposition, just above the upper } \\
\text { tree-limit lowered by sheep grazing }\end{array}$ \\
Karlowicz & 1520 & $\begin{array}{l}\text { Upper tree-limit, valley bottom of SN course } \\
\text { Dubrawiska }\end{array}$ \\
Wolarczyska & 1405 & Upper tree-limit, channel in the slope, NW exposition \\
\hline
\end{tabular}

disturbed) by human impact influence of relief on the upper tree-limit.

The site Dubrawiska was located within the slope in the channel bottom several tens of meters wide and a dozen or so meters deep (Fig.1). In this place the mountain pine makes a lobe and goes down to the altitude of $1400 \mathrm{~m}$, filling the channel bottom and partly its slopes. The data logger was installed at the tree-limit near the end of this lobe at the altitude of about $1405 \mathrm{~m}$ a.s.1.

The next measurement site - Wolarczyska was located about $100 \mathrm{~m}$ above the site 408. In this case it was not a dismembered part of the slope and it showed small inclination. Both sites were located at the slopes of NW exposition.

The third measurement site - Karlowicz was located in the valley bottom near the Czarny Potok Valley, close the monument of Karlowicz, about $0.5 \mathrm{~km}$ north of the threshold of Czarny Staw Gąsienicowy Lake. The valley in this place shows a $\mathrm{S}-\mathrm{N}$ course. The measurement site was located at the altitude of $1520 \mathrm{~m}$ a.s.l. just at the upper tree-limit (in this place it was probably its natural upper limit).

The last measurement site was installed in the research station at Hala Gąsienicowa at the altitude of about $1520 \mathrm{~m}$ a.s.l. The station shows SE exposition and it is situated above the upper tree-limit, which is lowered here by human impact.

\section{MATERIAL AND METHODS}

The measurements of air temperature were carried out every hour during day and night with the application of Onset HOBO data loggers which contained termistors of the accuracy $\pm 0.2^{\circ} \mathrm{C}$ and resolution $0.02^{\circ} \mathrm{C}$. The data loggers were hanged under the tree-crowns of large spruces at the height of $2 \mathrm{~m}$ and at the distance of $0.5 \mathrm{~m}$ north of the tree trunks. Additionally, each logger contained a special shield which protected it against a direct solar radiation. The measurements were carried out in the warm period during almost 4 months - from 22 June to 15 October. The data loggers were calibrated both before and after the measurement period. Their differences in showing the same temperature did not exceed $0.1^{\circ} \mathrm{C}$.

\section{RESULTS}

Fig. 2 shows temperatures recorded at all the four sites and smoothed by movable mean of the period 200 . Just a brief analysis reveals that the lowest temperature was recorded at the lowest located site Dubrawiska, and the highest temperature was recorded at the meteorological station. The largest differences in temperature between the sites occurred during anticyclone weather, and the lowest when atmospheric fronts were passing (strong winds). Tab. 2 shows mean values of temperature for individual sites calculated from all the measurements conducted in sites studied. The lowest mean temperature $7.9^{\circ} \mathrm{C}$ occurred in the lowest located site Dubrawiska. The highest mean temperature $9.2^{\circ} \mathrm{C}$ was recorded at the meteorological station. The difference between these sites amounted to $1.3^{\circ} \mathrm{C}$. If we take into consideration the differences of altitude and if we reduce the temperature in both sites to the 


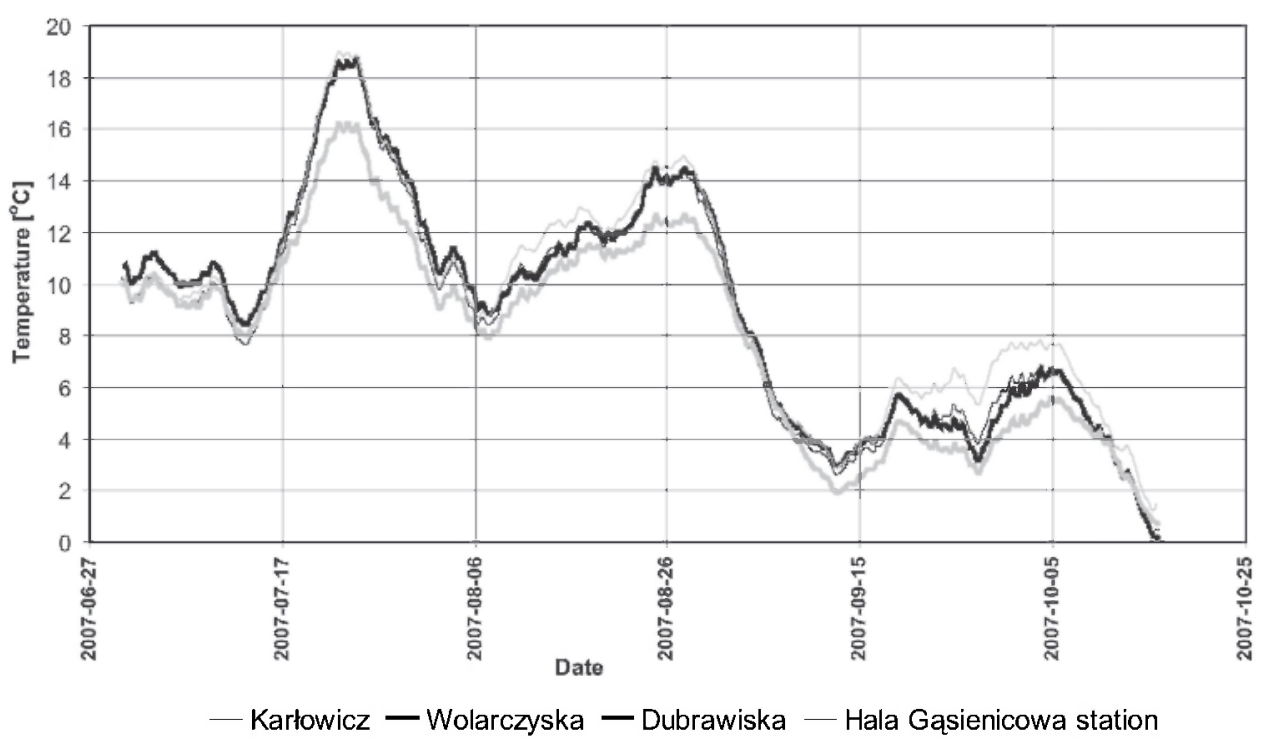

Figure 2. Air temperatures (smoothed by movable mean of period 200) in measurement sites.

Table 2. Temperature and altitude of measurement sites

\begin{tabular}{lllll}
\hline Site & Dubrawiska & Wolarczyska & Karlowicz & $\begin{array}{l}\text { Hala Gąsienicowa } \\
\text { station }\end{array}$ \\
\hline Altitude in $\mathrm{m}$ a.s.l. & 1405 & 1515 & $\mathbf{1 5 2 0}$ & $\mathbf{1 5 2 0}$ \\
Temperature $\left[{ }^{\circ} \mathrm{C}\right]$ & 7.9 & 8.8 & 8.6 & 9.2 \\
\hline
\end{tabular}

same height (assuming the gradient $0.6^{\circ} \mathrm{C}$ $1100 \mathrm{~m}$ ), the temperature difference between these two sites increases to $2^{\circ} \mathrm{C}$. In the two other sites, the temperature values were close to each other. A slightly lower temperature was recorded at the site Karlowicz in the bottom of the valley near Czarny Potok Valley, than in the not-dismembered part of the slope (site Karlowicz). This difference was $0.2^{\circ} \mathrm{C}$.

\section{DISCUSSION AND CONCLUSIONS}

The site Dubrawiska located about $100 \mathrm{~m}$ lower than the three other sites should show the highest temperature. In fact, this site showed the lowest temperature among all the others. This low temperature should not be explained by a northern exposition of the slope because the site Wolarczyska was also located at the slope of north exposition, but its temperature was higher by $0.9^{\circ} \mathrm{C}$. The most sensible explanation of the occurrence of such low temperature is the land relief. A concave form of a channel shape causes that a cold air flowing down the slope became canalised in the channel. Probably, at the end of the channel just near the upper tree-limit, the cold air additionally accumulates creating a frost hollow, which significantly influences the course of the upper tree-limit. This may be confirmed by the lobe of mountain pine mentioned earli$\mathrm{er}$, which in this place penetrates deeply the forest. The influence of avalanches on the course of the tree-line in the channel should be rather excluded because of high mountain pine vegetation, sporadic rachitic trees (spruces) which occur in the channel bottom and small slope inclination. The investigations of Baranowski (2003 a, b) which had 
been carried out several years earlier in Hala Gąsienicowa confirm that even small (several meters) linear depressions in the slope may reduce a mean temperature by several decimals ${ }^{\circ} \mathrm{C}$. The example of these two sites clearly illustrate a significant influence of relief on microclimate, and on the course of vegetation zones.

The highest temperature was recorded at the meteorological station. It is higher by $0.4^{\circ} \mathrm{C}$ than at the site Wolarczyska, despite the fact that these both sites are located at a similar altitude. The site Wolarczyska shows $\mathrm{N}$ exposition, whereas the meteorological station is located at the slope of Uhroć Kasprowy and shows SE exposition. The site Karlowicz shows the temperature lower by $0.6^{\circ} \mathrm{C}$ than the temperature at the station, and lower by $0.2^{\circ} \mathrm{C}$ than in the site Wolarczyska. In this case, the location of the site Karfowicz in the valley bottom considerably influenced the temperature. A rel- atively wide and flat bottom valley did not give such a cooling effect as it gave a much smaller channel at the site Dubrawiska. Nevertheless, a small temperature reduction connected with the flow or stagnation of cold air in the valley occurred in this site.

In the sites Dubrawiska, Wolarczyska and Karlowicz the data loggers were installed just near the upper tree-limit, only the research station is above the tree-limit. However, as it is seen in the Fig. 2, the tree-limit between Hala Gąsienicowa and Karczmisko reaches the altitude of about 1550-1560 m a.s.1. So, according to temperature course, the tree-limit here is higher than in other sites. The lack of forest in the neighbourhood of the station results from sheep grazing which occurred there several decades ago. The comparison of the photograph taken in 1907 by M. Karlowicz (Fig. 3) with the photograph taken in 2004 by T. Zwijacz-Kozica (Fig. 4) clearly illustrates

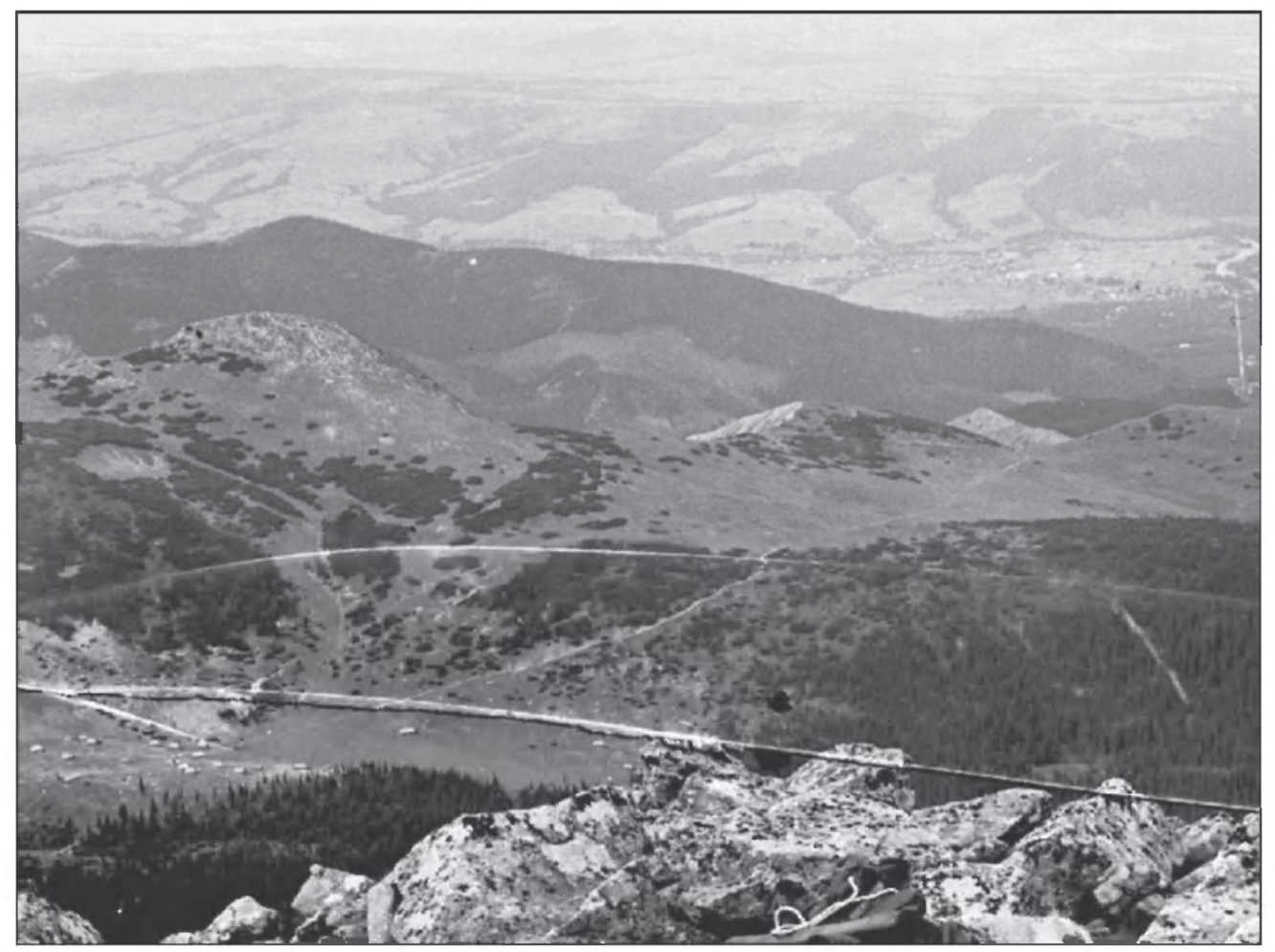

Figure 3. The view of Hala Gąsienicowa and Karczmisko. The photo taken in 1907 by M. Karłowicz. 


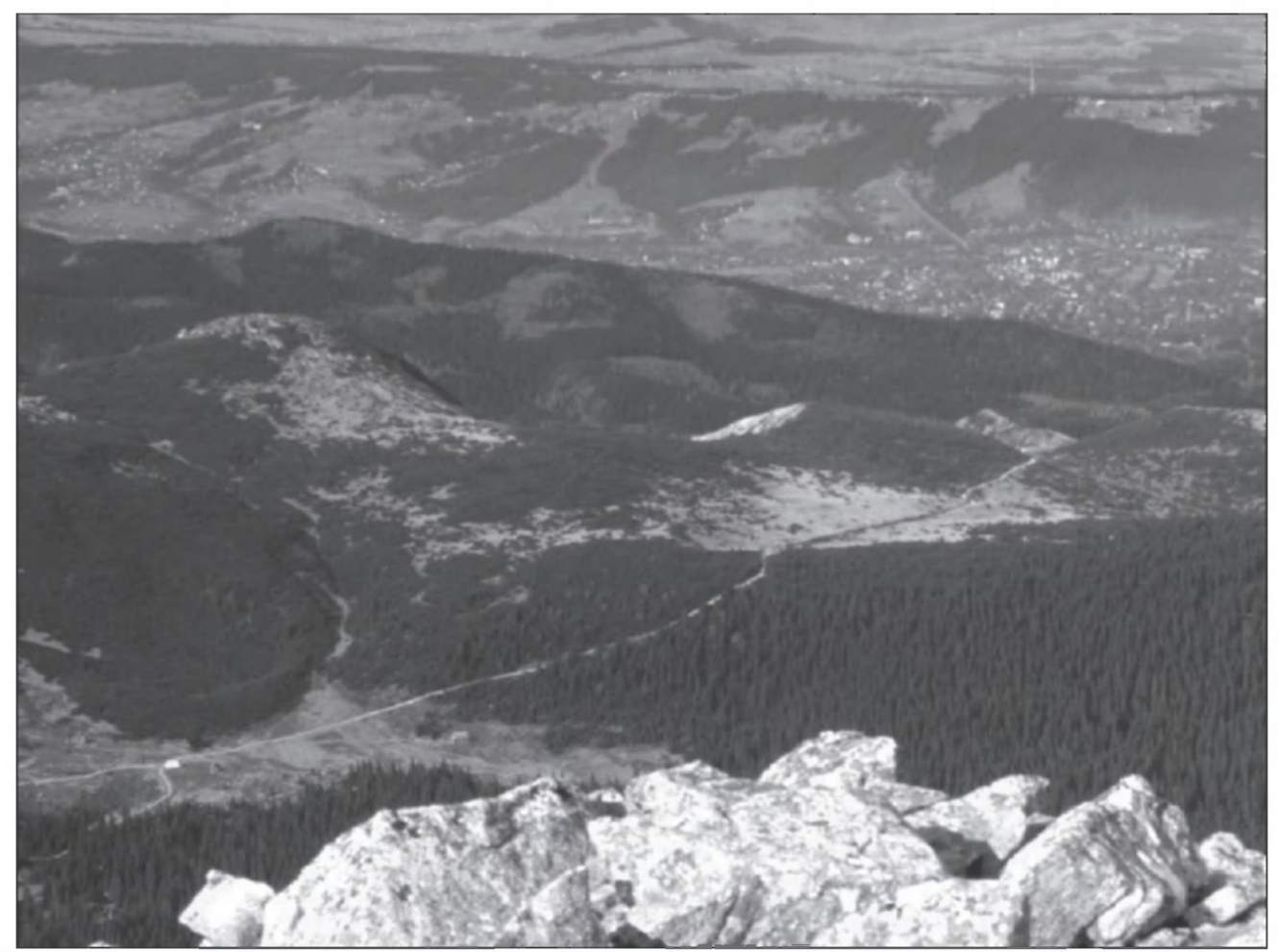

Figure 4. The view of Hala Gąsienicowa and Karczmisko. The photo taken in 2004 r. by T. Zwijacz-Kozica.

devastation done by sheep and shepherds both in the forest and mountain pine zones. Probably, if it was not for the sheep grazing, all Hala Gąsienicowa or its large part would be covered now by forest.

Despite the fact, that the investigations had only preliminary character, they clearly evidence a considerable relation between the relief, climate and the course of the upper tree-limit. The most distinct example is the site Dubrawiska, which is located about $100 \mathrm{~m}$ lower than the others sites so it should show higher temperature. However, because of a land relief in a form of a channel, this site showed the lowest temperature. The results of the investigations evidence that the course of the tree-limit (and probably also the mountain pine) should not be compared with the course of mean annual temperatures determined from interpolation and extrapolation. Only direct measurements in the field give a real picture of the relation between the relief and microclimate.

\section{ACKNOWLEDGEMENTS}

I wish to thank Prof. Adam Kotarba for his valuable remarks and suggestions concerning the investigations and the paper. I am grateful to Dr. engineer Tomász Zwijacz-Kozica for giving me run of his photos, for consultations, and his constructive criticism. I wish to acknowledge also The Board of Tatras National Park, for the permission to carry out the investigations in the Park's area.

The permission of the regional authorities (Permission of the Marshal of Malopolskie Voivodeship No. 12/2010) to use material of the state geodetic and cartographic resources is also acknowledged. 


\section{REFERENCES}

Balon, J. (1991a), Piętrowość w środowisku przyrodniczym Tatr [Zonation in the Tatra's natural environment], Czasopismo Geograficzne, 62: 283-299.

Balon, J. (1991b), From the methodology of distinguishing of vertical zones in the Tatra Mts., in: Theory and practice in landscape ecology, IX International Symposium on Problems of Landscape, Ecological Research, Dudince 1991, 199-208.

Balon, J. (2000), Piętra fizycznogeograficzne polskich Tatr [Physico-geographical belts of Polish Tatra Mountains], in Obrębska-Starkel, B. (ed.), Studies in physical geography, Prace Geograficzne, Kraków, 105: 211-233.

Baranowski, J. (2003a), Dynamika zmian dobowych i zróżnicowanie przestrzenne temperatury powietrza na Hali Gąsienicowej [The dynamic of daily fluctuation and the spatial differentiation of air temperature at Hala Gąsienicowa (Tatra Mts)], Przeglad Geograficzny, 75: 271-286.

Baranowski, J. (2003b), Lokalne zróżnicowanie warunków solarnych $w$ Tatrach $i$ jego zwiazki z rzeźba terenu i szata rosilinna (na przykladzie Hali Gasienicowej) [Local differentiation of solar radiation in the Tatras and its relationship with relief and flora (as exemplified by Hâla Gạsienicowa)]. Unpublished Ph.D. thesis, Instytut Geografii i Przestrzennego Zagospodarowania Polskiej Akademii Nauk, Warszawa, 193 ms. pp.

Fabianowski, J. (1955), Lasy tatrzańskie [Forests of Tatra Mountains], in Szafer, W. (ed.), Tatrzański Park Narodowy, Polska Akademia Nauk, Kraków, 73-131.

Heikkinen, O., Obrębska-Starkel, B. and Tuhkanen, S. (1995), Introduction: the timberline - a changing battlefront, Prace Geograficzne UJ, 98: 7-16.

Hess, M. (1965), Piętra klimatyczne w polskich Karpatach Zachodnich [Vertical climatic zones in the Polish western Carpathians], Zeszyty Naukowe UJ, Prace Geograficzne, 11: 1-268.

Hess, M. (1974), Piętra klimatyczne Tatt Polskich [Climatic belts of Polish Tatra Mountains], Czasopismo Geograficzne, 45: 75-95.

Jodłowski, M. (2007), Górna granica kosodrzewiny w Tatrach, na Babiej Górze i w Karkono- szach [Krummholz-line in the Tatra Mts., Babia Góra and the Giant Mts.], Instytut Geografii i Gospodarki Przestrzennej Uniwersytetu Jagiellońskiego, Kraków, 188 pp.

Kotarba, A. (1987), Geoecological belts, in Kotarba, A. (ed.), High mountain denudational system of the Polish Tatra Mountains, Geographical Studies, Special Issue 3, Instytut Geografii i Przestrzennego Zagospodarowania (IGiPZ), PAN: 48-56.

Krzemień, K., Libelt, P. and Mączka, T. (1995), Geomorphological conditions of the timberline in the Western Tatra Mountains, Prace Geograficzne UJ, 98: 153-170.

Myczkowski, S. (1964), Struktura i ekologia zespołu świerka Picetum tatricum u górnej granicy zasięgu w Tatrzańskim Parku Narodowym w dolinach Rybiego Potoku, Roztoki, Waksmundzkiej i Pańszczycy [The structure and ecology of Picetum tatricum spruce association at the upper limit in Tatra National Park in the Rybi Potok, Roztoka Waksmundzka and Pańsczyca valleys], Ochrona Przyrody, 28: 83-110.

Pawłowski, B. (1972), Szata roślinna gór Polski [Plant cover of Polish mountains], in Szafer, W. (ed.), Szata mślinna Polski, 2nd Ed., Wydawnictwo Naukowe PWN, Warszawa, 189-252.

Piękoś-Mirkowa, H. and Mirek, Z. (1996), Zbiorowiska roślinne [Plant communities], in Mirek, Z. (ed.), Przyroda Tatrzańskiego Parku Narodowego, Tatrzański Park Narodowy, Kraków-Zakopane, 237-274.

Sokołowski, M. (1928), O górnej granicy lasu w Tatrach [About the upper timberline in the Tatra Mountains], Wydawnictwo Fundacji „Zaklady Kórnickie”, Kraków, 188 pp.

Szafer, W. (1966), Dziesięć tysięcy lat historii lasu w Tatrach [Ten thousand years of forest history in the Tatra Mountains], Nauka dla wszystkich, 1, Polska Akademia Nauk, Oddział w Krakowie, Kraków, 34 pp.

Zientarski, J. (1985), Wplyw wzniesienia oraz wielkości masywu górskiego na kształtowanie się górnej granicy lasu w Polsce [The influence of elevation and size of a mountain massif on the distribution of the upper timberline], Akademia Rolnicza, Poznań, 153 pp.

Paper first received: June 2010

In final form: November 2010 
http://rcin.org.pl 